\title{
Induction of Plant Defense Gene Expression by Plant Activators and Pseudomonas syringae pv. tomato in Greenhouse-Grown Tomatoes
}

\author{
M. A. B. Herman, J. K. Davidson, and C. D. Smart
}

First and third authors: Department of Plant Pathology and Plant-Microbe Biology, Cornell University, New York State Agricultural Experiment Station, Geneva, NY 14456; and second author: Department of Biology, Hobart and William Smith Colleges, Geneva, NY 14456.

Accepted for publication 23 July 2008.

ABSTRACT

\begin{abstract}
Herman, M. A. B., Davidson, J. K., and Smart, C. D. 2008. Induction of plant defense gene expression by plant activators and Pseudomonas syringae pv. tomato in greenhouse-grown tomatoes. Phytopathology 98:1226-1232.

Plant activators provide an appealing management option for bacterial diseases of greenhouse-grown tomatoes. Two types of plant activators, one that induces systemic acquired resistance (SAR) and a second that activates induced systemic resistance (ISR), were evaluated for control of Pseudomonas syringae pv. tomato and effect on plant defense gene activation. Benzothiadiazole (BTH, SAR-inducing compound) effectively reduced bacterial speck incidence and severity, both alone and in combi-
\end{abstract}

nation with the ISR-inducing product. Application of BTH also led to elevated activation of salicylic acid and ethylene-mediated responses, based on real-time polymerase chain reaction analysis of marker gene expression levels. In contrast, the ISR-inducing product (made up of plant growth-promoting rhizobacteria) inconsistently modified defense gene expression and did not provide disease control to the same level as did BTH. No antagonism was observed by combining the two activators as control of bacterial speck was similar to or better than BTH alone.

Additional keywords: Bacillus spp., induced defense responses, Solanum lycopersicum.
Plant activators induce plant defense responses known as systemic acquired resistance (SAR) or induced systemic resistance (ISR) $(37,41)$. Commercially available compounds that induce SAR (such as benzothiadiazole) and ISR-inducing plant growthpromoting rhizobacteria (PGPR) have been shown to be effective for disease control in tomato $(2,10,18,19,23,27,32)$. However, few studies examine utilization of these products together as an integrated control strategy or have investigated their combined impact on plant defense responses $(2,12,16,27,32)$.

Marker genes can be used to better understand how these products activate plant defense responses. Induction of salicylic acid (SA)-mediated responses or SAR can be followed using the expression level of the acidic $P R-1$ gene as a marker $(5,40,42)$. This gene is activated by compounds such as benzothiadiazole (BTH) and in response to abiotic and biotic stress $(11,14)$. Ethylene (ET) is thought to enhance and stimulate defense responses; activation of these responses can be followed using the basic $P R-1$ marker gene $(5,40,42,45)$. ET-mediated responses may be involved in PGPR-plant interactions due to the role of ETregulated pathways in expression of ISR (44). The expression level of a proteinase inhibitor gene, Pin2, can be utilized to measure induction of wound-inducible jasmonic acid (JA) signaling $(7,13,30)$. JA-mediated responses are activated when a plant is wounded, such as by insect herbivory or pathogen lesion formation, and are also thought to be involved in ISR $(6,19,31,39)$.

Plant defense responses are interconnected and both antagonism and synergy between these phytohormone signaling networks is known $(6,22)$. Activation of ISR and SAR simultaneously in a laboratory setting has been shown to provide additive disease control in the $P$. syringae pv. tomato-Arabidopsis pathosystem

Corresponding author: C. D. Smart; E-mail address: cds14@cornell.edu

doi:10.1094/PHYTO-98-11-1226

(C) 2008 The American Phytopathological Society
(46). Utilizing this same pathosystem, Ramos Solano et al. (32) also found disease control with additive effects of the SA and ET pathways, depending on which type of PGPR was used. One PGPR strain, Chryseobacterium balustinum, induced both the SAR and ISR pathways by initially activating the SA-dependent pathway (SAR), followed by stimulation of the SA-independent pathway (ISR) (32).

In New York State, tomato production is predominantly for fresh market. Tomato seedlings are grown in the greenhouse until 5 to 7 weeks of age and then transplanted into the field (33). Large numbers of plants in a relatively small, confined space with overhead irrigation facilitates rapid spread of bacterial diseases through a greenhouse. Pseudomonas syringae pv. tomato is the causal agent of bacterial speck disease of tomato $(17,24,29)$. This persistent disease can be economically important under conducive conditions such as cool temperatures (18 to $\left.24^{\circ} \mathrm{C}\right)$ and high relative humidity $(15,17)$. Symptomatic plants typically exhibit small, necrotic lesions surrounded by chlorotic halos on foliage and fruit. While this disease does not often kill the plant, symptoms on fruit can decrease marketability. The identification of control strategies that could effectively control bacterial disease in the greenhouse could aid transplant production.

The goal of this study was to determine whether the SAR plant activator (BTH) and the ISR plant activator (Bacillus spp.), utilized alone or in combination, would effectively control $P$. syringae pv. tomato in greenhouse-grown tomato transplants. Additionally, SA-, JA-, and ET-mediated defenses were followed in response to activators and pathogen inoculation and assessed using quantitative real-time polymerase chain reaction (PCR).

\section{MATERIALS AND METHODS}

Plant materials and treatments. Tomato (Solanum lycopersicon) cv. Sunchief VF was used for all experiments. The greenhouse used for these experiments was maintained at 23 to $26^{\circ} \mathrm{C}$ 
(day) and 20 to $22^{\circ} \mathrm{C}$ (night) with $15 \mathrm{~h}$ of natural light and approximately $40 \%$ relative humidity. Tomato seeds were sown in 128 cell polystyrene flats in the greenhouse in Cornell mix (a soilless peat mixture), perlite, and vermiculite (4:1:1). Tomatoes were divided into four treatments: untreated control, plants grown in the presence of PGPR, BTH applied to foliage, and the combination of plants grown in the presence of PGPR and foliage treated with BTH. The PGPR treatment, BioYield Concentrate (Bayer CropScience, Research Triangle Park, NC), was mixed evenly into the potting mix at planting $\left(1.2 \mathrm{~kg} / \mathrm{m}^{3}\right)$. This PGPR product contains $4.1 \times 10^{4}$ endospores of two bacterial strains, Bacillus subtilis GB03 and B. amyloliquefaciens IN937a, per $\mathrm{cm}^{3}$. After 4 weeks, all tomatoes were transferred to 4 -inch pots. Sixto seven-week-old plants were used for this study. BTH (Actigard $50 \mathrm{WG}$, Syngenta Crop Protection, Greensboro, NC) was applied at the highest recommended rate $(52 \mathrm{~g} / \mathrm{ha}) 4$ days prior to pathogen inoculation.

Pathogen inoculation and disease rating. The experiment was arranged in a randomized complete block design, with three plots of each of the four treatments at each of the four tissue collection times (tissue collection described below) per experiment. Each plot consisted of three potted tomato plants; thus, with three replicates per treatment, there were a total of nine plants per treatment and collection time per experiment. From each plot of three plants, one was used for disease rating, while tissue was collected from the other two to test for defense response gene expression (described below). Each experiment consisted of 144 plants (3 plants per plot $\times 3$ replicates $\times 4$ collection time points $\times$ 4 treatments) and the entire experiment was conducted three times.

Isolate A9 of P. syringae pv. tomato was cultured in $100 \mathrm{ml}$ of nutrient broth (35) with shaking at $180 \mathrm{rpm}$ overnight at $28^{\circ} \mathrm{C}$. This isolate was collected from a diseased tomato plant in the field in 2003 and stored at $-80^{\circ} \mathrm{C}$. Five milliliters of this inoculum was transferred to each of 15 flasks containing $500 \mathrm{ml}$ of nutrient broth and cultured overnight as above. Prior to inoculation, bacteria were spun down at $20,000 \times g$ for $15 \mathrm{~min}$ and rinsed with $10 \mathrm{mM} \mathrm{MgCl}$. Bacteria were resuspended in $10 \mathrm{mM} \mathrm{MgCl}_{2}$ containing $200 \mu \mathrm{l} /$ liter of the surfactant Silwet L77 (Helena Chemical, Collierville, TN) to a concentration of $10^{8} \mathrm{CFU} / \mathrm{ml}$ and applied to runoff with a pump sprayer. All plants (untreated control, PGPR, BTH, and BTH+PGPR) were inoculated.

One plant from each treatment plot was rated for disease incidence and disease severity 7 days after inoculation. The number of diseased leaflets and the total number of leaflets per plant were recorded for disease incidence. To determine severity, all leaflets from each plant were placed into one of six rating categories: 0,1 to 10,11 to 25,26 to 50,51 to 100 , and >100 lesions per leaflet.

Analyses of disease ratings. Bacterial speck incidence, measured by the proportion of leaflets per plant containing bacterial lesions, was analyzed using quasi-likelihood models (25). Means were compared using a chi-square test at $P=0.05$. The control efficacy of the plant activators, represented by percent disease control of bacterial speck relative to the untreated control was calculated as described by Baider and Cohen (3). Specifically, percent control was calculated using the following formula: 1 $x / y \times 100$, where $x=$ mean bacterial speck incidence in treated plants and $y=$ mean bacterial speck incidence in control plants. Synergism between the two plant activators was assessed using the Abbott method and the Gowing formula (20). The Gowing formula is as follows: expected percent control $=(a+b-a \times b) \times$ 100 , where $a$ and $b=$ mean bacterial speck incidence of acibenzolar- $S$-methyl- and PGPR-treated plants, respectively. An ordinal proportional odds logistic regression was used to model the relationship between treatment and bacterial speck disease severity (36). The odds of a treatment resulting in less disease severity than the untreated control (having fewer numbers of leaflets in higher disease severity categories) was determined with a $95 \%$ confidence interval for each of the three experiments.

Tissue collection and RNA extraction and purification. All tomato leaflets above the three oldest leaves were collected from two plants per plot at four time points $(-12,12,36$, and $60 \mathrm{~h}$ relative to pathogen inoculation). Leaf tissue from both plants was combined in a single bag, flash frozen in liquid nitrogen immediately after collection, and stored at $-80^{\circ} \mathrm{C}$. RNA was extracted from $1 \mathrm{~g}$ of tissue with the SV Total RNA Isolation System (Promega Corporation, Madison, WI) and further DNase treated with Turbo DNA-free (Ambion Inc., Austin, TX). Samples were visualized by electrophoresis on a $1.2 \%$ agarose formaldehyde gel.

Analysis of gene expression using quantitative real-time PCR. Two-step real-time PCR was performed using the iCycler iQ Real-Time PCR Detection System (Bio-Rad Laboratories, Hercules, CA) and utilized fluorogenic probe technology. Two micrograms of total RNA was used to generate cDNA with the iScript cDNA synthesis kit (Bio-Rad Laboratories) according to the manufacturer's instructions. Controls lacking reverse transcriptase were included to check for DNA contamination. Gene expression was quantified from each cDNA sample using four tomato genes, actin (a housekeeping gene), acidic $P R-1$, basic $P R-1$, and Pin2. Real-time PCR primers and probes for tomato acidic and basic $P R-1$ were identical to those described by Block et al. (5). Tomato actin and Pin2 primers and probes were designed using Primer Express 2.0 software (Applied Biosystems, Foster City, CA) and were as follows: actin probe 5'-/6-FAM/CGTTTGGATCTTGCTGGTCGTGATTTAACT/TAMRA/-3'; actin forward primer 5'-TTGCCGCATGCCATTCT-3'; actin reverse primer 5'-TCGGTGAGGATATTCATCAGGTT-3'; Pin2 probe 5'/6-FAM/TGTGGTAATCTTGGGTTCGGGATATGCC/TAMRA/3'; Pin2 forward primer 5'-TGATGCCAAGGCTTGTACTAGAGA-3'; Pin2 reverse primer 5'-AGCGGACTTCCTTCTGAACGT-3' (Integrated DNA Technologies, Coralville, IA). Both probes were labeled with 6-carboxyfluorescein (FAM) at the $5^{\prime}$ end and TAMARA quencher dye at the $3^{\prime}$ end.

Real-time quantitative PCR reactions were carried out in triplicate; each reaction utilized the iQ Supermix Kit (Bio-Rad Laboratories) and consisted of $1 \times$ Mastermix, forward and reverse primers (300 $\mathrm{nM}$ final concentration) and $200 \mathrm{nM}$ fluorogenic probe. Reaction parameters consisted of $95^{\circ} \mathrm{C}$ for $4 \mathrm{~min}$, followed by 45 cycles of $95^{\circ} \mathrm{C}$ for $10 \mathrm{~s}, 50^{\circ} \mathrm{C}$ for $1 \mathrm{~min}$, and $72^{\circ} \mathrm{C}$ for $30 \mathrm{~s}$. In addition to cDNA reaction samples lacking reverse transcriptase, reactions with no cDNA template were also included as negative controls.

Initial transcript levels were determined using the standard curve method (User Bulletin 2, ABI PRISM 7700 Sequence Detection System, Relative quantification of gene expression, 2001, Applied Biosystems). Serial dilutions of tomato total genomic DNA were used to generate standard curves (47). Standard curve construction was accomplished by plotting the threshold cycle $(\mathrm{Ct})$ against the logarithm of the known tomato DNA dilutions. The absolute quantity of the product in each sample was calculated from these curves $(9,26)$. Subsequently, tomato actin (used as an internal control) was utilized to normalize tomato defense gene expression and generate relative expression values (REVs) (4). Relative expression change was calculated by calibrating samples to the mean REV of the three replicates (within each experiment) prior to pathogen inoculation ( $-12 \mathrm{~h}$ time point) for each of the four treatments. The log of the REVs for each of the three marker genes tested was used to determine statistical significance. Analysis of variance using the Proc Mixed procedure and SAS software version 9.1 (SAS Institute, Cary, NC) was used to analyze these values (26). Differences between treatments were evaluated using orthogonal contrasts at each time point and $P$ values of $<0.05$ were considered statistically significant (26). Data are presented as fold change relative to a calibrator sample, which 
was untreated control plants at the $-12 \mathrm{~h}$ time point (prior to pathogen inoculation).

\section{RESULTS}

Bacterial speck incidence. Incidence of $P$. syringae pv. tomato, as measured by the mean proportion of infected leaflets per plant, followed a similar pattern in all three experiments $(P=$ 0.30 , Table 1). Incidence was not significantly different between the untreated control and PGPR-treated plants $(P=0.119,0.9177$, and 0.12 , respectively). Both BTH $(P<0.0001, P=0.0244$, and $P<0.0001$, respectively) and BTH in combination with the PGPR product $(P<0.0001, P=0.0003$, and $P<0.0001)$ significantly reduced bacterial speck incidence in all three experimental replicates. Synergy between BTH and the PGPR product was observed in one of the three experiments (Table 1).

Bacterial speck severity. In the three experiments, disease severity in all treatments differed significantly from the untreated control $(P<0.0001$, Table 2$)$. The average number of leaflets per plant in each disease severity category is depicted by treatment and experiment in Table 2. Plants grown in the presence of the PGPR product were less severely infected than the control in two of the three experiments $(P<0.05)$. Plants that received BTH treatment consistently exhibited less severe symptoms than untreated control and PGPR-treated plants $(P<0.05)$. In one experiment, BTH+PGPR-treated plants were less severely infected than those treated with BTH alone.

Effect of treatment on marker gene activation. Level of defense gene expression was effectively quantified for each of the three defense response marker genes (relative to actin) via quantitative real-time PCR for each of the four treatments. Complete results for each of the three experiments are divided by marker gene (Figs. 1 to 3 ) and are presented by treatment (untreated control, PGPR-treated, BTH-treated, and BTH+PGPR-treated) below.
Acidic PR-1 transcript levels. In all three experiments, the untreated control demonstrated low levels of acidic $P R-1$ expression prior to pathogen inoculation (Fig. 1, white bars). Over the course of the experiment, activation of SA-mediated responses increased gradually to highest levels at $60 \mathrm{~h}$ after inoculation (16.9-, 10.2-, and 4.9-fold increase from $-12 \mathrm{~h}, P=0.0005, P<$ 0.0001 , and $P<0.0001$ ).

PGPR-treated plants had similar levels of acidic $P R-1$ expression to the untreated control prior to pathogen inoculation in all three experiments (Fig. 1, striped bars). Induction of SA-mediated responses increased to highest expression levels at 60 (Fig. 1A and C) and 36 (Fig. 1B) hours postinfection (6.3-, 4.8-, and 8.8fold increase from $-12 \mathrm{~h}, P=0.0005, P<0.0001$, and $P=$ 0.0002). Peak expression relative to the untreated control varied by experiment; no significant differences were observed in experiment 1. PGPR-treated plants had repressed acidic $P R-1$ activation compared with the untreated control in experiment two and significantly greater expression in experiment three.

Treatment with BTH 3 days prior to pathogen inoculation activated acidic $P R-1$ at the -12 h time point to levels 3- to 13fold higher than the untreated control (Fig. 1, gray bars). Levels were elevated throughout the course of the experiment, increasing after inoculation to highest levels at the 36 (Fig. 1B and C) or $60 \mathrm{~h}$ time points (Fig. 1A). By $60 \mathrm{~h}$, acidic $P R-1$ transcript abundance in BTH-treated plants was not significantly different from untreated control plants.

As seen with BTH treatment alone, the combination of plant activators induced acidic $P R-1$ activation 3- to 7-fold higher than the untreated control prior to inoculation (Fig. 1, black bars). Transcript abundance increased over the course of the experiment to peak levels at the 36 (Fig. 1B and C) or $60 \mathrm{~h}$ time points (Fig. 1A). As observed with BTH treatment, acidic $P R-1$ expression did not differ significantly from untreated control at the $60 \mathrm{~h}$ time point.

Basic PR-1 transcript levels. Basic $P R-1$ expression followed a similar pattern in untreated control plants as acidic $P R-1$, with

TABLE 1. Disease incidence of Pseudomonas syringae pv. tomato in greenhouse-grown tomatoes over three experiments

\begin{tabular}{|c|c|c|c|c|c|c|c|c|}
\hline \multirow[b]{2}{*}{ Experiment } & \multirow{2}{*}{$\begin{array}{c}\begin{array}{c}\text { Untreated } \\
\text { control }^{\mathrm{v}}\end{array} \\
\text { Proportion }^{\mathrm{w}}\end{array}$} & \multicolumn{2}{|c|}{$\begin{array}{l}\text { Plant growth-promoting } \\
\text { rhizobacteria (PGPR) }\end{array}$} & \multicolumn{2}{|c|}{ Benzothiadiazole (BTH) } & \multicolumn{2}{|c|}{$\mathrm{BTH}+\mathrm{PGPR}$} & \multirow{2}{*}{$\begin{array}{c}\text { Expected } \\
\text { percent } \\
\text { controly }^{\mathrm{y}}\end{array}$} \\
\hline & & Proportion & Percent control $^{\mathrm{x}}$ & Proportion & Percent control & Proportion & Percent control & \\
\hline 1 & $0.53 \pm 0.04 \mathrm{a}^{\mathrm{z}}$ & $0.44 \pm 0.04 \mathrm{a}$ & 17 & $0.18 \pm 0.03 b$ & 66 & $0.15 \pm 0.03 b$ & 72 & 72 \\
\hline 2 & $0.42 \pm 0.05 \mathrm{a}$ & $0.42 \pm 0.05 \mathrm{a}$ & 0 & $0.26 \pm 0.05 b$ & 38 & $0.16 \pm 0.04 b$ & 62 & 38 \\
\hline 3 & $0.46 \pm 0.04 \mathrm{a}$ & $0.37 \pm 0.04 \mathrm{a}$ & 20 & $0.15 \pm 0.03 b$ & 67 & $0.15 \pm 0.03 b$ & 67 & 74 \\
\hline Average & & & 12 & & 57 & & 67 & \\
\hline
\end{tabular}

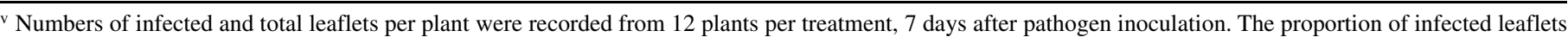
per plant was analyzed using quasi-likelihood models and means were compared using a chi-square test at $P=0.05$.

${ }^{w}$ Mean proportion of infected leaflets per plant averaged for three replicates \pm standard error.

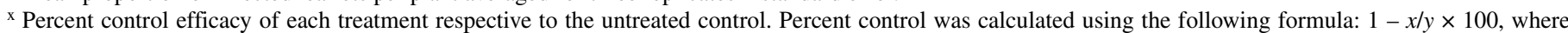
$x=$ mean bacterial speck incidence in treated plants and $y=$ mean bacterial speck incidence in control plants.

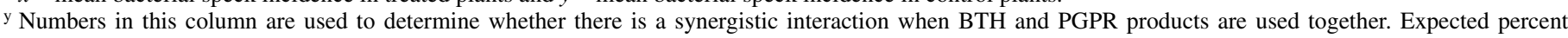
control was calculated as follows: $(a+b-a \times b) \times 100$, where $a, b=$ mean bacterial speck incidence of acibenzolar- $S$-methyl- and PGPR-treated plants, respectively. If the percent control is greater than the expected control, a synergistic interaction between the two products has occurred.

${ }^{\mathrm{z}}$ Means within a row sharing the same letter are not statistically different.

TABLE 2. Disease severity of Pseudomonas syringae pv. tomato over three greenhouse experiments

\begin{tabular}{|c|c|c|c|c|c|c|c|c|c|c|c|c|}
\hline \multirow[b]{2}{*}{ Severity ${ }^{y}$} & \multicolumn{3}{|c|}{ Untreated control } & \multicolumn{3}{|c|}{$\begin{array}{l}\text { Plant growth-promoting } \\
\text { rhizobacteria (PGPR) }\end{array}$} & \multicolumn{3}{|c|}{ Benzothiadiazole (BTH) } & \multicolumn{3}{|c|}{$\mathrm{BTH}+\mathrm{PGPR}$} \\
\hline & $1^{\mathrm{z}}$ & 2 & 3 & 1 & 2 & 3 & 1 & 2 & 3 & 1 & 2 & 3 \\
\hline 0 & 15 & 32 & 29 & 18 & 30 & 32 & 26 & 41 & 48 & 28 & 49 & 48 \\
\hline 1 to 10 & 11 & 20 & 19 & 12 & 19 & 16 & 5 & 12 & 8 & 5 & 9 & 8 \\
\hline 11 to 25 & 3 & 2 & 4 & 2 & 1 & 3 & 1 & 2 & 0 & 0 & 0 & 1 \\
\hline 26 to 50 & 2 & 1 & 1 & 1 & 1 & 0 & 0 & 0 & 0 & 0 & 0 & 0 \\
\hline 51 to 100 & 1 & 0 & 0 & 0 & 0 & 0 & 0 & 0 & 0 & 0 & 0 & 0 \\
\hline$>100$ & 0 & 0 & 0 & 0 & 0 & 0 & 0 & 0 & 0 & 0 & 0 & 0 \\
\hline
\end{tabular}

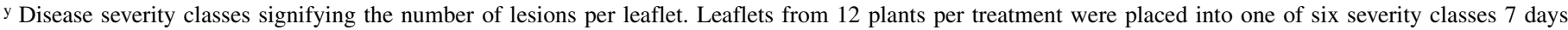
following inoculation: 0,1 to 10,11 to 25,26 to 50,51 to 100 , and $>100$ lesions per leaflet.

$\mathrm{z}$ The mean number of leaflets per disease rating category for each experiment $(1,2$, and 3$)$ is presented. 
low expression levels prior to pathogen inoculation, increasing to highest levels $60 \mathrm{~h}$ after inoculation (Fig. 2, white bars). By $60 \mathrm{~h}$, basic $P R-1$ expression was significantly higher than levels observed prior to inoculations in each of the three experiments (8.9-, 5.8-, and 5.4-fold increase from $-12 \mathrm{~h}, P=0.0005, P=0.0001$, and $P<0.0001)$.

In PGPR-treated plants, activation of ET-mediated responses was similar to acidic $P R-1$, with low expression levels prior to inoculation and increasing to highest levels 36 (Fig. 2B, striped bars) or $60 \mathrm{~h}$ (Fig. 2A and C) after inoculation. At peak levels, basic $P R-1$ expression was significantly higher than levels observed prior to inoculations in each of the three experiments (4.4-, 4.2-, and 4.9-fold increase from $-12 \mathrm{~h}, P=0.0155, P<0.0001$, and $P<0.0009$ ). In two experiments, PGPR-treated plants exhibited significantly lower activation of ET-mediated responses (Fig. 2A and B) compared with the untreated control, while no significant differences were found in the third experiment (Fig. 2C).
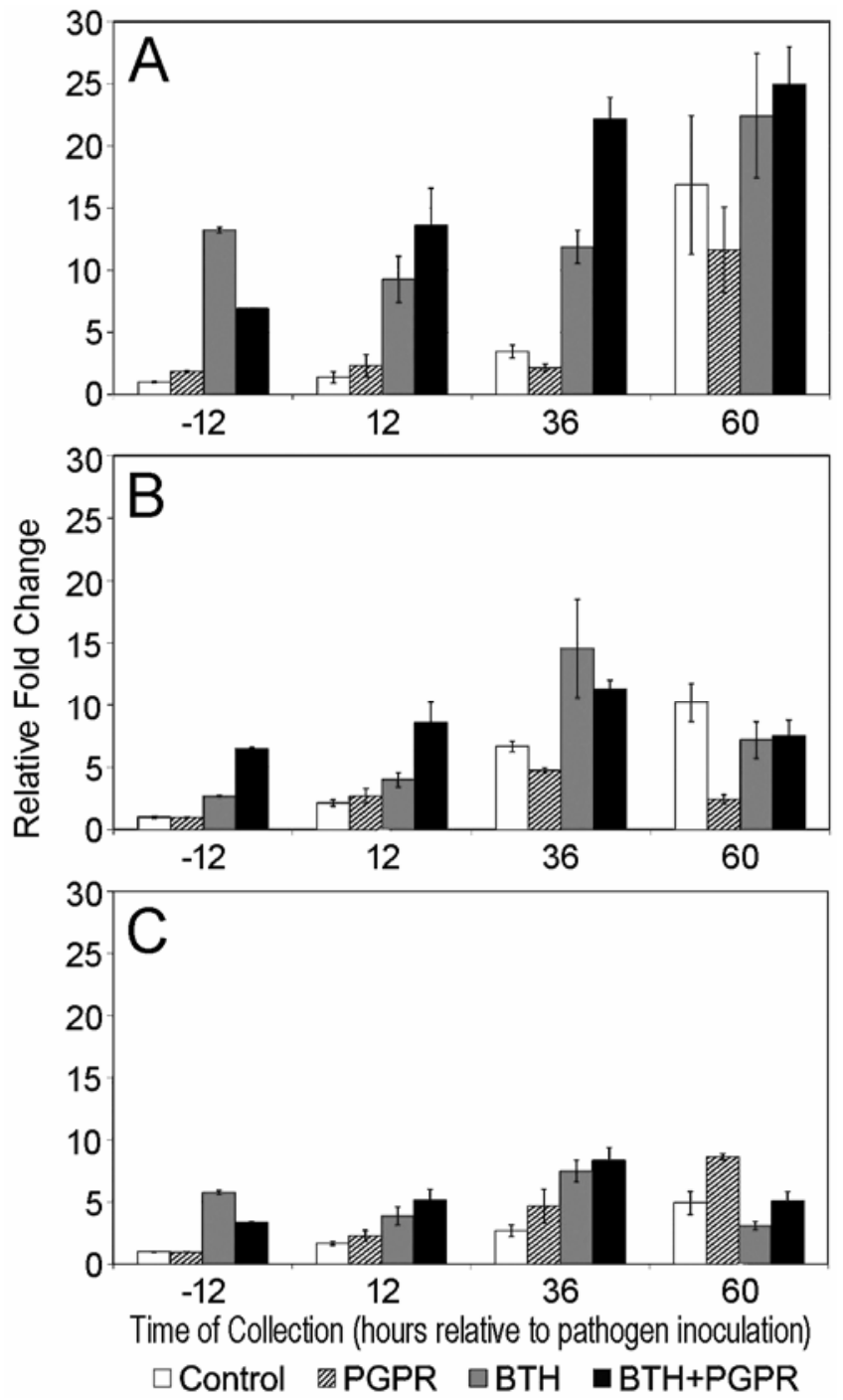

Fig. 1. Expression pattern of tomato gene acidic $P R-1$ following inoculation with Pseudomonas syringae pv. tomato. All treatments were inoculated at time 0 . A, Experiment 1; B, experiment 2; and $\mathbf{C}$, experiment 3. Solid white bars represent relative fold change of three replicated plots of untreated control plants, striped bars represent plant growth-promoting rhizobacteria (PGPR)treated plants, gray bars indicate benzothiadiazole (BTH)-treated plants, and black bars correspond to plants treated with both BTH and PGPR. Bars represent average induction $( \pm S E)$ of gene transcripts normalized to the housekeeping gene actin for three replicate plots. Fold change was calculated by calibrating data to the untreated control prior to bacterial inoculation $(-12 \mathrm{~h})$.
BTH treatment also induced ET-mediated responses prior to inoculation to levels 3- to 7-fold higher than the untreated control (Fig. 2, gray bars). Peak activation followed a similar pattern to acidic $P R-1$ expression in all three experiments, with levels increasing after inoculation to highest levels at 36 (Fig. 2B and C) or $60 \mathrm{~h}$ (Fig. 2A) postinoculation. By $60 \mathrm{~h}$, basic $P R-1$ expression was not significantly different from the untreated control in two experiments (Fig. 2A and B) and repressed in one (Fig. 2C).

ET-mediated responses were also induced in plants treated with BTH and PGPR prior to inoculation, as expression of the basic $P R-1$ gene was 4- to 7.5-fold higher than the untreated control at $-12 \mathrm{~h}$ (Fig. 2, black bars). A similar pattern to acidic $P R-1$ expression was observed following inoculation, with levels increasing to highest levels at 36 (Fig. 2C) or $60 \mathrm{~h}$ (Fig. 2A and B). One difference from acidic $P R-1$ expression was observed in experiment 2, where peak activation of ET-mediated responses occurred 1 day later, at the $60 \mathrm{~h}$ time point (Figs. 1B and 2B). Expression levels were not significantly different from the untreated control
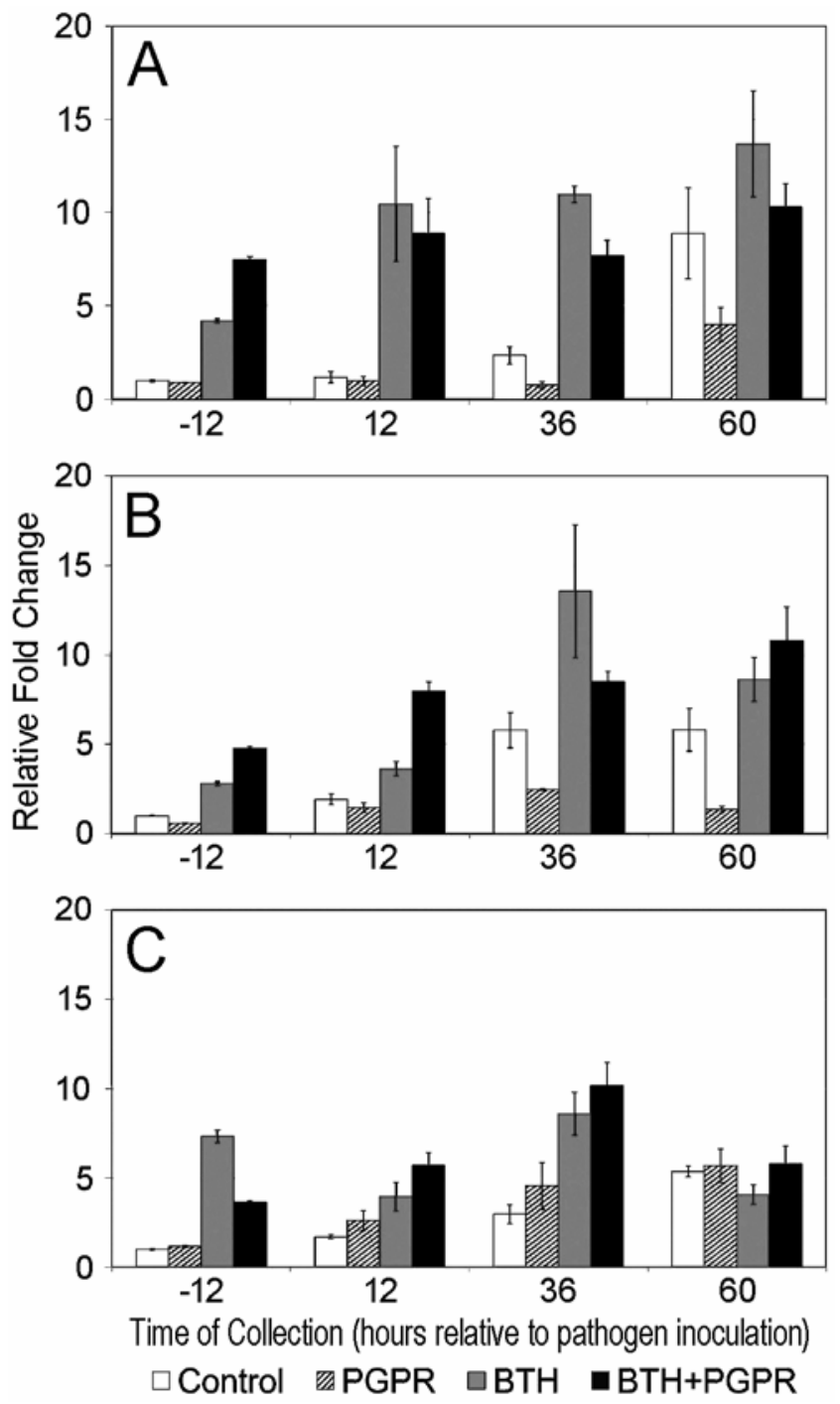

Fig. 2. Expression pattern of tomato gene basic $P R-1$ following inoculation with Pseudomonas syringae pv. tomato. All treatments were inoculated at time 0 . A, Experiment 1; B, experiment 2; and $\mathbf{C}$, experiment 3. Solid white bars represent relative fold change of three replicated plots of untreated control plants, striped bars represent plant growth-promoting rhizobacteria (PGPR)treated plants, gray bars indicate benzothiadiazole (BTH)-treated plants, and black bars correspond to plants treated with both BTH and PGPR. Bars represent average induction $( \pm \mathrm{SE})$ of gene transcripts normalized to the housekeeping gene actin for three replicate plots. Fold change was calculated by calibrating data to the untreated control prior to bacterial inoculation $(-12 \mathrm{~h})$. 
at $60 \mathrm{~h}$ in two experiments (Fig. 2A and C) and induced in one (Fig. 2B).

Pin2 transcript levels. Wound-induced signaling in untreated control plants dramatically increased from low levels $12 \mathrm{~h}$ prior to inoculation to highest levels at $60 \mathrm{~h}$ (Fig. 3, white bars). Large changes in transcript abundance were observed in JA-mediated responses at $60 \mathrm{~h}$ postinoculation in each experiment (205.7-, 7.2-, and 3.2-fold change from uninoculated plants at $-12 \mathrm{~h}, P<$ $0.0001,0.0001$, and 0.0001).

Pin2 transcript levels dramatically increased from $12 \mathrm{~h}$ prior to inoculation to highest levels at $60 \mathrm{~h}$ in PGPR-treated plants (Fig. 3 , striped bars). At peak induction of JA-mediated responses, large changes in transcript levels were observed in each experiment (39.0-, 4.3-, and 10.7-fold increase from $-12 \mathrm{~h}, P=0.0001$, $P<0.0093$, and $P<0.0049$ ). Variability between experiments was observed with the PGPR-treated plants not differing by $60 \mathrm{~h}$ from the untreated control (Fig. 3A), repressed in experiment 2 (Fig. 3B) and induced in experiment 3 (Fig. 3C).
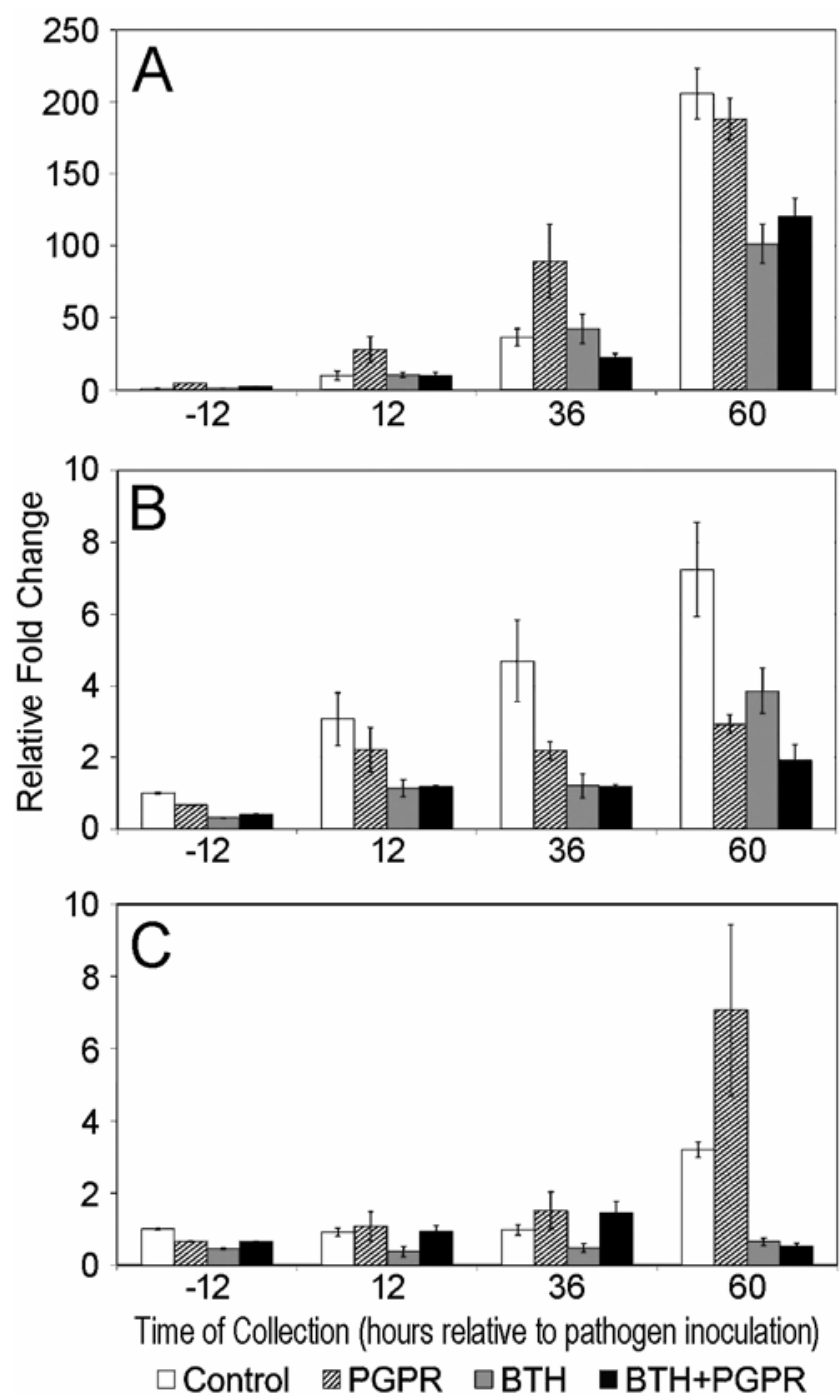

Fig. 3. Expression pattern of tomato gene Pin2 following inoculation with Pseudomonas syringae pv. tomato. All treatments were inoculated at time 0. A, Experiment 1; B, experiment 2; and $\mathbf{C}$, experiment 3. Solid white bars represent relative fold change of three replicated plots of untreated control plants, striped bars represent plant growth-promoting rhizobacteria (PGPR)treated plants, gray bars indicate benzothiadiazole (BTH)-treated plants, and black bars correspond to plants treated with both BTH and PGPR. Bars represent average induction $( \pm \mathrm{SE})$ of gene transcripts normalized to the housekeeping gene actin for three replicate plots. Fold change was calculated by calibrating data to the untreated control prior to bacterial inoculation $(-12 \mathrm{~h})$.
Over the time course, Pin2 levels significantly increased in BTH-treated plants in two of the three experiments, though expression levels observed were down-regulated by 50 to $80 \%$ relative to untreated controls (Fig. 3, gray bars). Induction of JAmediated responses increased to highest levels by the $60 \mathrm{~h}$ time point in each experiment (74.1-, 12.1-, and 1.4-fold change from uninoculated plants at $-12 \mathrm{~h}, P<0.0001, P<0.0001$, and $P=$ 0.2239).

Expression of Pin2 increased following inoculation in BTH+ PGPR-treated plants, though levels were repressed (41 to $84 \%$ lower) relative to the untreated controls (Fig. 3, black bars). Greatest induction of JA-mediated responses occurred at the 60 (Fig. 3A and B) or $36 \mathrm{~h}$ (Fig. 3C) time point (44.4-, 4.7-, and 2.2fold change from uninoculated plants at $-12 \mathrm{~h}, P<0.0001, P<$ 0.0001 , and $P=0.6371)$.

\section{DISCUSSION}

Data presented in this study provide support for the incorporation of plant activators in greenhouse management of bacterial diseases. Treatment with the PGPR product reduced bacterial speck symptoms relative to the untreated control in two of the three experiments, though not to a commercially acceptable level. In contrast, BTH effectively reduced bacterial speck incidence and severity both alone and in combination with the PGPR product, in agreement with previous studies $(21,23,34)$. Usage of both activators together resulted in lower disease incidence than BTH alone in one experiment and lower infection severity in two experiments.

Symptom development correlated to wound-induced gene expression (Pin2). Plants exhibiting higher levels of disease (untreated control, PGPR-treated) demonstrated a larger increase in Pin2 transcript levels. Previous studies have found production of coronatine, a JA mimic and phytotoxin, by $P$. syringae pv. tomato to be correlated with induction of wound-responsive genes in susceptible tomato $(38,48)$. In contrast, BTH-treated plants displayed significantly lower levels of Pin2 gene expression, alone or in combination with the PGPR product, than the untreated control at $60 \mathrm{~h}$. This reflects the reduced disease severity in plants treated with BTH. Expression levels of PGPR-treated plants did not reflect the level of disease relative to the untreated control, as response ranged from the same, lower, and higher Pin 2 expression in PGPR plots. Part of this variation may be due to high variability between PGPR-treated plants in experiment 3 at the $60 \mathrm{~h}$ time point. One replicate demonstrated much higher Pin2 transcript levels than the other two, consequently inflating the mean expression and standard error. While gene expression differences between the three experiments may also be due to environmental differences in the greenhouse that influenced the growth of the pathogen, the outcome was still the same. Treatment with BTH effectively controlled disease, whereas the PGPR product did not provide commercially acceptable control. Utilization of both compounds in concert did not negatively impact SAR as acidic $P R-1$ expression was similar between BTH+PGPR- and BTH-treated plants with disease control as good as or better than using the BTH compound alone.

Previous studies have found that SA- and ET-mediated responses increase during compatible interactions between bacterial pathogens and tomato $(5,45,48)$. Plants that exhibited higher levels of bacterial speck lesions (untreated control and PGPRtreated) also demonstrated increasing acidic and basic $P R-1$ levels over the course of the experiment following inoculation. Untreated controls reached peak expression of both acidic and basic $P R-1$ at $60 \mathrm{~h}$ after inoculation, whereas the response of PGPRtreated plants was variable.

Treatment with BTH induced SA- and ET-mediated responses prior to inoculation, alone or in combination with the PGPR product, in all three experiments. A 3- to 13-fold increase in both 
acidic and basic $P R-1$ transcript levels was observed at the $-12 \mathrm{~h}$ collection time for plants treated with BTH compared with untreated control plants. Plants remained activated throughout the duration of the experiment and each marker gene was induced to a greater degree following pathogen inoculation. There was no evidence for antagonistic effects of activating the SAR and ISR responses in concert as no consistent differences were found in expression of the three marker genes between BTH- and BTH+ PGPR-treated plants. Synergy between the two products is possible as disease incidence and severity was reduced in one experiment.

In previous studies, PGPR products have not been associated with major changes in defense gene expression (43) though some strains of Bacillus and Chryseobacterium have been found to activate defense-related marker genes $(28,32)$. It is possible that the PGPR product primed plants to respond more quickly and to a greater degree following inoculation (Figs. 1C, 2C, and 3A and C) though the effect was inconsistent. Alfano et al. (1) found several tomato genes upregulated via Trichoderma induction of systemic resistance, including extensin and osmotin. Possibly these markers could provide more information regarding the PGPRtomato interaction as Trichoderma spp. have been found to induce defenses in a manner similar to PGPR (8).

Although the PGPR product used in this study failed to provide sufficient bacterial speck control, growth-promoting benefits of this product were not analyzed. Previous work has shown that PGPR can be effective in transplant and field production $(18,19)$. While copper is currently the most widely utilized control measure, incorporation of BTH into greenhouse transplant production could be useful for bacterial speck control. Combining the two products may provide the disease control benefits of BTH while boosting plant yield; however, further investigation of these plant activators in a production system is necessary.

\section{ACKNOWLEDGMENTS}

We thank H. Lange for technical assistance, J. Barnard for statistical support, and T. Glover (Hobart and William Smith Colleges) for thoughtful discussions and advice. This project was supported by the New York State IPM competitive grants program, the New York State Agricultural Experiment Station, and by a grant from the office of the provost of Hobart and William Smith Colleges.

\section{LITERATURE CITED}

1. Alfano, G., Ivey, M. L. L., Cakir, C., Bos, J. I. B., Miller, S. A., Madden, L. V., Kamoun, S., and Hoitink, H. A. J. 2007. Systemic modulation of gene expression in tomato by Trichoderma hamatum 382. Phytopathology 97:429-437.

2. Anith, K. N., Momol, M. T., Kloepper, J. W., Marois, J. J., Olson, S. M., and Jones, J. B. 2004. Efficacy of plant growth-promoting rhizobacteria, acibenzolar-S-methyl, and soil amendment for integrated management of bacterial wilt on tomato. Plant Dis. 88:669-673.

3. Baider, A., and Cohen, Y. 2003. Synergistic interaction between BABA and mancozeb in controlling Phytophthora infestans in potato and tomato and Pseudoperonospora cubensis in cucumber. Phytoparasitica 31:399-409.

4. Beaubois, E., Girard, S., Lallechere, S., Davies, E., Paladian, F., Bonnet, P., Ledoigt, G., and Vian, A. 2007. Intercellular communication in plants: Evidence for two rapidly transmitted systemic signals generated in response to electromagnetic field stimulation in tomato. Plant Cell Environ. 30:834-844.

5. Block, A., Schmelz, E., O’Donnell, P. J., Jones, J. B., and Klee, H. J. 2005. Systemic acquired tolerance to virulent bacterial pathogens in tomato. Plant Physiol. 138:1481-1490.

6. Bostock, R. M. 2005. Signal crosstalk and induced resistance: Straddling the line between cost and benefit. Annu. Rev. Phytopathol. 43:545-580.

7. Bowles, D. 1998. Signal transduction in the wound response of tomato plants. Philos. Trans. R. Soc. Lond. B Biol. Sci. 353:1495-1510.

8. Conrath, U., Beckers, G. J. M., Flors, V., Garcia-Agustin, P., Jakab, G., Mauch, F., Newman, M. A., Pieterse, C. M. J., Poinssot, B., Pozo, M. J., Pugin, A., Schaffrath, U., Ton, J., Wendehenne, D., Zimmerli, L., and Mauch-Mani, B. 2006. Priming: Getting ready for battle. Mol. PlantMicrobe Interact. 19:1062-1071.
9. Ding, J. Y., Jia, J. W., Yang, L. T., Wen, H. B., Zhang, C. M., Liu, W. X., and Zhang, D. B. 2004. Validation of a rice specific gene, sucrose phosphate synthase, used as the endogenous reference gene for qualitative and real-time quantitative PCR detection of transgenes. J. Agric. Food Chem. 52:3372-3377.

10. Domenech, J., Reddy, M. S., Kloepper, J. W., Ramos, B., and GutierrezManero, J. 2006. Combined application of the biological product LS213 with Bacillus, Pseudomonas or Chryseobacterium for growth promotion and biological control of soil-borne diseases in pepper and tomato. Biocontrol 51:245-258.

11. Durrant, W. E., and Dong, X. 2004. Systemic acquired resistance. Annu. Rev. Phytopathol. 42:185-209.

12. Fakhouri, W. D., Neemann, M., Walker, F., and Buchenauer, H. 2004. Application of fluorescent pseudomonads in combination with acibenzolar- $S$-methyl induces disease resistance in tomato and tobacco. J. Plant Dis. Prot. 111:494-505.

13. Fidantsef, A. L., Stout, M. J., Thaler, J. S., Duffey, S. S., and Bostock, R. M. 1999. Signal interactions in pathogen and insect attack: Expression of lipoxygenase, proteinase inhibitor II, and pathogenesis-related protein P4 in the tomato, Lycopersicon esculentum. Physiol. Mol. Plant Pathol. 54:97-114.

14. Friedrich, L., Lawton, K., Ruess, W., Masner, P., Specker, N., Rella, M. G., Meier, B., Dincher, S., Staub, T., Uknes, S., Metraux, J. P., Kessmann, H., and Ryals, J. 1996. A benzothiadiazole derivative induces systemic acquired resistance in tobacco. Plant J. 10:61-70.

15. Goode, M. J., and Sasser, M. 1980. Prevention-The key to controlling bacterial spot and bacterial speck of tomato. Plant Dis. 64:831-834.

16. Ji, P., Campbell, H. L., Kloepper, J. W., Jones, J. B., Suslow, T. V., and Wilson, M. 2006. Integrated biological control of bacterial speck and spot of tomato under field conditions using foliar biological control agents and plant growth-promoting rhizobacteria. Biol. Control. 36:358-367.

17. Jones, J. B., Stall, R. E., and Zitter, T. A. (eds.) 1991. Compendium of Tomato Diseases. American Phytopathological Society, St. Paul, MN.

18. Kloepper, J. W., Reddy, M. S., Rodriguez-Kabana, R., Kenney, D. S., Kokalis-Burelle, N., and Martinez-Ochoa, N. 2004. Application for rhizobacteria in transplant production and yield enhancement. Acta Hortic. 631:217-229.

19. Kloepper, J. W., Ryu, C. M., and Zhang, S. A. 2004. Induced systemic resistance and promotion of plant growth by Bacillus spp. Phytopathology 94:1259-1266.

20. Kosman, E., and Cohen, Y. 1996. Procedures for calculating and differentiating synergism and antagonism in action of fungicide mixtures. Phytopathology 86:1263-1272.

21. Lawton, K. A., Friedrich, L., Hunt, M., Weymann, K., Delaney, T., Kessmann, H., Staub, T., and Ryals, J. 1996. Benzothiadiazole induces disease resistance in Arabidopsis by activation of the systemic acquired resistance signal transduction pathway. Plant J. 10:71-82.

22. Lorenzo, O., and Solano, R. 2005. Molecular players regulating the jasmonate signaling network. Curr. Opin. Plant Biol. 8:532-540.

23. Louws, F. J., Wilson, M., Campbell, H. L., Cuppels, D. A., Jones, J. B., Shoemaker, P. B., Sahin, F., and Miller, S. A. 2001. Field control of bacterial spot and bacterial speck of tomato using a plant activator. Plant Dis. 85:481-488.

24. Madigan, M. T., Martinko, J. M., and Parker, J. (eds.) 2003. Brock Biology of Microorganisms. 10th ed. Pearson Education, Inc., Upper Saddle River, NJ.

25. McCullagh, P. 1983. Quasi-likelihood functions. Ann. Statist. 11:59-67.

26. Mittapalli, O., Shukle, R. H., Sardesai, N., Giovanini, M. P., and Williams, C. E. 2006. Expression patterns of antibacterial genes in the Hessian fly. J. Insect Physiol. 52:1143-1152.

27. Obradovic, A., Jones, J. B., Momol, M. T., Olson, S. M., Jackson, L. E., Balogh, B., Guven, K., and Iriarte, F. B. 2005. Integration of biological control agents and systemic acquired resistance inducers against bacterial spot on tomato. Plant Dis. 89:712-716.

28. Ongena, M., Duby, F., Jourdan, E., Beaudry, T., Jadin, V., Dommes, J., and Thonart, P. 2005. Bacillus subtilis M4 decreases plant susceptibility towards fungal pathogens by increasing host resistance associated with differential gene expression. Appl. Microbiol. Biotech. 67:692-698.

29. Pedley, K. F., and Martin, G. B. 2003. Molecular basis of Pto-mediated resistance to bacterial speck disease in tomato. Annu. Rev. Phytopathol. 41:215-243.

30. Penacortes, H., Fisahn, J., and Willmitzer, L. 1995. Signals involved in wound-induced proteinase-inhibitor-II gene-expression in tomato and potato plants. Proc. Natl. Acad. Sci. USA 92:4106-4113.

31. Pieterse, C. M. J., Van Wees, S. C. M., Ton, J., Van Pelt, J. A., and Van Loon, L. C. 2002. Signaling in rhizobacteria-induced systemic resistance in Arabidopsis thaliana. Plant Biol. 4:535-544.

32. Ramos Solano, B., Barriuso Maicas, J., Pereyra de la Iglesia, M. T., Domenech, J., and Gutierrez Manero, F. J. 2008. Systemic disease protection elicited by plant growth promoting rhizobacteria strains: 
Relationship between metabolic responses, systemic disease protection, and biotic elicitors. Phytopathology 98:451-457.

33. Reiners, S., and Petzoldt, C. (eds.) 2007. The Integrated Crop and Pest Management Guidelines For Vegetables. Cornell University Press, Ithaca, NY.

34. Scarponi, L., Buonaurio, R., and Martinetti, L. 2001. Persistence and translocation of a benzothiadiazole derivative in tomato plants in relation to systemic acquired resistance against Pseudomonas syringae pv. tomato. Pest Manag. Sci. 57:262-268.

35. Schaad, N. W., Jones, J. B., and Chun, W. (eds.) 2001. Laboratory Guide for Identification of Plant Pathogenic Bacteria. 3rd ed. American Phytopathological Society, St. Paul, MN.

36. Scott, S. C., Goldberg, M. S., and Mayo, N. E. 1997. Statistical assessment of ordinal outcomes in comparative studies. J. Clin. Epidemiol. 50:45-55.

37. Stout, M. J., Fidantsef, A. L., Duffey, S. S., and Bostock, R. M. 1999. Signal interactions in pathogen and insect attack: Systemic plantmediated interactions between pathogens and herbivores of the tomato, Lycopersicon esculentum. Physiol. Mol. Plant Pathol. 54:115-130.

38. Strassner, J., Schaller, F., Frick, U. B., Howe, G. A., Weiler, E. W., Amrhein, N., Macheroux, P., and Schaller, A. 2002. Characterization and cDNA-microarray expression analysis of 12-oxophytodienoate reductases reveals differential roles for octadecanoid biosynthesis in the local versus the systemic wound response. Plant J. 32:585-601.

39. Thaler, J. S., Fidantsef, A. L., and Bostock, R. M. 2002. Antagonism between jasmonate- and salicylate-mediated induced plant resistance: Effects of concentration and timing of elicitation on defense-related proteins, herbivore, and pathogen performance in tomato. J. Chem. Ecol. 28:1131-1159.

40. Tornero, P., Gadea, J., Conejero, V., and Vera, P. 1997. Two PR-1 genes from tomato are differentially regulated and reveal a novel mode of expression for a pathogenesis-related gene during the hypersensitive response and development. Mol. Plant-Microbe Interact. 10:624-634.

41. Vallad, G. E., and Goodman, R. M. 2004. Systemic acquired resistance and induced systemic resistance in conventional agriculture. Crop Sci. 44:1920-1934.

42. van Kan, J. A., Joosten, M. H., Wagemakers, C. A., van den BergVelthuis, G. C., and de Wit, P. J. 1992. Differential accumulation of mRNAs encoding extracellular and intracellular PR proteins in tomato induced by virulent and avirulent races of Cladosporium fulvum. Plant Mol. Biol. 20:513-527.

43. van Loon, L. C. 1999. Occurrence and properties of plant pathogenesisrelated proteins. Pages 1-20 in: Pathogenesis-Related Proteins in Plants. S. K. Datta and S. Muthukrishnan, eds. CRC Press, Boca Raton, FL.

44. van Loon, L. C., Geraats, B. P. J., and Linthorst, H. J. M. 2006. Ethylene as a modulator of disease resistance in plants. Trends Plant Sci. 11:184-191.

45. van Loon, L. C., Rep, M., and Pieterse, C. M. J. 2006. Significance of inducible defense-related proteins in infected plants. Annu. Rev. Phytopathol. 44:135-162.

46. van Wees, S. C. M., de Swart, E. A. M., van Pelt, J. A., van Loon, L. C., and Pieterse, C. M. J. 2000. Enhancement of induced disease resistance by simultaneous activation of salicylate- and jasmonate-dependent defense pathways in Arabidopsis thaliana. Proc. Natl. Acad. Sci. USA 97:8711-8716

47. Yun, J. J., Heisler, L. E., Hwang, I. I. L., Wilkins, O., Lau, S. K., Hyrcza, M., Jayabalasingham, B., Jin, J., McLaurin, J., Tsao, M. S., and Der, S. D. 2006. Genomic DNA functions as a universal external standard in quantitative real-time PCR. Nucleic Acids Res. 34:E85-E85.

48. Zhao, Y., Thilmony, R., Bender, C. L., Schaller, A., He, S. Y., and Howe, G. A. 2003. Virulence systems of Pseudomonas syringae pv. tomato promote bacterial speck disease in tomato by targeting the jasmonate signaling pathway. Plant J. 36:485-499. 